\title{
GEOINFORMATION ANALYSIS OF THE POTENTIAL OF HUMAN RESOURCES OF AGRICULTURAL TERRITORIES OF VOLGOGRAD REGION ${ }^{1}$
}

\author{
Natalya M. Khavanskaya \\ Volgograd State University, Volgograd, Russian Federation \\ Vladimir A. Alyaev \\ Volgograd State University, Volgograd, Russian Federation \\ Diana A. Semenova \\ Volgograd State University, Volgograd, Russian Federation
}

\begin{abstract}
The purpose of this research is to assess the degree of auspiciousness of the human resources potential of the agricultural territories of Volgograd region, its territorial structure. The authors use the classical methodological approach of economic geography in conjunction with modern geographic information systems. The study includes three stages. The first is the collection and processing of statistical data on the main indicators of human resources of rural settlements such as number, density, age composition. The second stage includes the compilation of thematic maps for the selected indicators, the allocation of classes for the ranges of values of indicators and their spatial analysis. The third stage is the creation of an integrated map for a set of indicators with the allocation of territories according to the degree of auspiciousness of the potential of human resources. As a result, the main characteristics of the rural population of Volgograd region are identified. It has been established that most of the rural settlements belong to large rural settlements. Zones of increased and decreased density of the rural population are identified. According to the estimation of the age composition made by calculating the aging index, the rural population is in the stage of deep and very deep aging. Geoinformation mapping methods allow not only statistical processing of data, but also spatial analysis of the distribution of mapped indicators. The geoinformation analysis of the human potential of agricultural territories allows us to talk about the mosaic nature of its territorial structure, the alternation of territories with varying degrees of its development.

Key words: geoinformation mapping, human resources, number of inhabitants, population density, ageing index, agricultural territories.

Citation. Khavanskaya N.M., Alyaev V.A., Semenova D.A. Geoinformation Analysis of the Potential of Human Resources of Agricultural Territories of Volgograd Region. Journal of Volgograd State University. Economics, 2020, vol. 22, no. 2, pp. 109-118. (in Russian). DOI: https://doi.org/10.15688/ek.jvolsu.2020.2.10

\section{ГЕОИНФОРМАЦИОННЫЙ АНАЛИЗ ПОТЕНЦИАЛА ЧЕЛОВЕЧЕСКИХ РЕСУ РСОВ АГРАРНЫХ ТЕРРИТОРИЙ ВОЛГОГРАДСКОЙ ОБЛАСТИ ${ }^{1}$}

\author{
Наталья Михайловна Хаванская
}

Волгоградский государственный университет, г. Волгоград, Российская Федерация

Владимир Алексеевич Аляев

Волгоградский государственный университет, г. Волгоград, Российская Федерация 


\section{Диана Александровна Семенова}

Волгоградский государственный университет, г. Волгоград, Российская Федерация

Аннотация. Цель данной работы заключается в оценке степени благоприятности потенциала человеческих ресурсов аграрных территорий Волгоградской области, его территориальной структуры. Авторы используют классический методологический подход экономической географии в комплексе с современными геоинформационными системами. Исследование включает три этапа. Первый - сбор и обработка статистических данных по основным показателям человеческих ресурсов сельских поселений, таких как численность, плотность, возрастной состав. Второй этап включает составление тематических карт по выбранным показателям, выделение классов по диапазонам значений показателей и их пространственный анализ. Третий этап - составление интегральной карты по комплексу показателей с выделением территорий по степени благоприятности потенциала человеческих ресурсов. В результате выявлены основные характеристики сельского населения Волгоградской области. Установлено, что большая часть сельских поселений относятся к крупным сельским населенным пунктам. Выявлены зоны повышенной и пониженной плотности сельского населения. Согласно оценке возрастного состава, осуществленной через расчет индекса старения, сельское население находится в стадии глубокой и очень глубокой стадии старения. Методы геоинформационного картографирования дают возможность не только провести статистическую обработку данных, но и осуществить пространственный анализ распределения картографируемых показателей. Геоинформационный анализ потенциала человеческих ресурсов аграрных территорий позволяет говорить о мозаичности его территориальной структуры, чередовании территорий с разной степенью его развития.

Ключевые слова: геоинформационное картографирование, человеческие ресурсы, численность населения, плотность населения, индекс старения, аграрные территории.

Цитирование. Хаванская Н. М., Аляев В. А., Семенова Д. А. Геоинформационный анализ потенциала человеческих ресурсов аграрных территорий Волгоградской области // Вестник Волгоградского государственного университета. Экономика. - 2020. - Т. 22, № 2. - С. 109-118. - DOI: https://doi.org/10.15688/ ek.jvolsu.2020.2.10

\section{Введение}

В настоящее время геоинформационные системы (далее - ГИС) находят широкое применение в различных отраслях экономики. Развитие добывающих отраслей, точного земледелия, территориального планирования, управление хозяйственным комплексом на разных уровнях сегодня невозможно представить без ГИС. Совмещение баз данных, широкого статистического функционала с возможностями пространственного анализа и создания геоинформационнокартографических моделей незаменимо в социально-экономических исследованиях, основанных на анализе и классификации больших массивов статистических данных. Визуализация результатов этого анализа в виде карт позволяет максимально точно в сжатой форме выявить закономерности пространственного распределения изучаемых объектов и явлений.

Известно, что в настоящее время в мире продолжаются процессы урбанизации. Боль- ше половины населения мира проживает в городах. Тем не менее именно на сельское население ложится вся нагрузка по производству сельскохозяйственной продукции.

Актуальность исследования проблем расселения сельского населения также определена в «Стратегии устойчивого развития сельских территорий в Российской Федерации на период до 2030 года». Из этого документа следует, что размещение хозяйства на территориальном уровне сел и сельских поселений зависит от наличия ресурсов общего пользования, к которым относятся численность и плотность сельского населения, что в совокупности отражает потенциал живого труда. На наш взгляд, необходимо учитывать и возрастной состав населения, отражающий его трудоспособность. Таким показателем является индекс старения населения, рассчитываемый как отношение числа пожилых к числу детей в возрасте до 15 лет.

Одним из направлений исследований социально-экономической географии является 
проблема расселения населения аграрных территорий. В современной мировой экономикогеографической науке доминируют исследования, отражающие классические методологические подходы [Галин, 2015; Егоров и др., 2018; Руднева и др., 2019; Alekseev et al., 2015]. Данная работа представляет собой одно из направлений, проводимых авторами исследований сельских поселений Волгоградской области [Аляев и др., 2013; Аляев и др., 2016; Вишняков и др., 2016; Анализ ... , 2019].

Волгоградская область расположена в степной зоне юга России. Благоприятные агроклиматические условия и равнинный рельеф еще в историческом прошлом способствовали развитию здесь сельского хозяйства: земледелия и животноводства. По данным Федеральной службы государственной статистики по Волгоградской области в 2018 г. площадь посевных площадей составила 3 171,2 тыс. га или около $28 \%$ всей территории региона

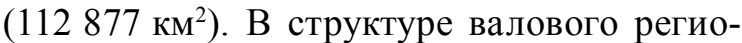
нального продукта в основных ценах на сельское и лесное хозяйство, охоту, рыболовство в 2017 г. приходилось 12,3\%, что соответствует третьему месту после обрабатывающего производства и оптовой и розничной торговли. Численность сельского населения региона в 2019 г. составила 22,9 \%, или 573768 человек. Все перечисленные показатели, соответствующие индустриально-аграрному этапу хозяйственного развития, и определяют необходимость изучения потенциала человеческих ресурсов аграрных территорий региона.

\section{Материалы и методы}

При проведении территориальных исследований актуальными являются методологические основы, сформированные на основе использования работы П. Тойна, П. Ньюби [Тойн и др., 1977]. При изучении экономико-географических проблем расселения значительное внимание уделяется формированию общей логики исследования, которая складывается из характеристики разнообразных методов сбора информации, методов статистической обработки данных, методов наглядного представления данных, методов исследования размещения. Важное значение для экономико-географического исследова- ния имеют методы геоинформационного картографирования [Ивлиева и др., 2017; Тимонин, 2011] и сетевого анализа размещения сельских населенных пунктов [Freeman, 1978; Pitts, 1965].

Геоинформационный анализ сельского населения Волгоградской области основан на использовании статистических данных, представленных на официальном сайте Волгоградстата, и электронных картографических материалов. Анализ был проведен на двух уровнях территориальной организации: сельских поселений и муниципальных районов Волгоградской области. Всего было рассмотрено 408 сельских поселений и один городской округ - Михайловка, объединивший в себе 14 сельских поселений, поэтому в составе населения кроме городского, имеющего и сельское. По этим муниципальным образованиям собраны и систематизированы в электронной таблице данные о численности сельского населения на 1 января 2020 года.

По 32 муниципальным районом собраны и систематизированы данные возрастного состава сельского населения на 1 января 2020 г., включая группы: от 0 до 14 лет включительно и население старше трудоспособного возраста.

К картографическим материалам относится электронный слой административнотерриториально деления Волгоградской области, включающий полигоны сельских поселений и муниципальных районов. Геоинформационный анализ проводился в программной среде ESRI ArcGIS 10.3. Для проектирования геоинформационно-картографических моделей выбрана проекция WGS_84 UTM 38 Zone, которая обладает минимальными искажениями для картографируемой территории Волгоградской области и пригодна для автоматического расчета площадей сельских поселений. Базовый масштаб проектируемых моделей - $1: 3000000$.

В геоинформационном анализе сельского населения мы выделили ряд этапов.

Первый этап - подготовительный, включает в себя сбор статистических данных, оформление их в электронный вид таблицы Excel, совместимый с электронным слоем административно-территориального деления Волгоградской области в ArcGIS. 
Второй этап - составление и анализ тематических карт. Охватывает процессы классификации картографируемых показателей и составление соответствующих тематических карт. В начале этапа составленная таблица Excel с данными о численности и возрастном составе сельского населения была импортирована в ArcGIS и соединена со слоем административно-территориального деления Волгоградской области. Дальнейшая обработка данных и представление картографических результатов анализа основаны на классификации соответствующих числовых полей.

Геоинформационный анализ численности населения сельских поселений основан на классификации вручную с использованием прогрессивной шкалы. Величина начального интервала классификации, равная 500 чел., выбрана в соответствии с принципами классификации населенных пунктов по людности и фактическими статистическими данными, находящимися в интервале значений от 152 до 24383 . При переходе от одного класса к другому происходит увеличение интервала на значение, равное ему. Так, было выделено 7 классов сельских поселений по числу жителей: 152-500; 501-1 000; 1 001-2 000; 2 001-3 500; 3 501-5 500; 5 5017 000; 7 001-9 101.

Ввиду большого разрыва значений по численности сельского населения данные по городскому округу Михайловка - 24383 чел. - исключены из классификации и вынесены отдельно. По результатам классификации построена карта «Численность сельского населения сельских поселений Волгоградской области».

Значения плотности сельского населения были получены автоматически с помощью функции «Калькулятор поля» делением поля «Численность населения» на поле «Площадь» в атрибутивной таблице слоя административно-территориального деления. При классификации сельских поселений по плотности населения также была использована прогрессивная шкала и метод классификации вручную. В данном случае начальный интервал классификации составил 2 чел./км ${ }^{2}$. Таким образом, выделено 5 классов поселений по плотности населения (чел./км²): $1-2 ; 3-4 ; 5-8 ; 9-$ $14 ; 15$ и более.
Пространственный анализ индекса старения населения был приведен для муниципальных районов Волгоградской области в соответствие с территориальным охватом статистических данных Волгоградстата [Federal State Statistics Service, 2020]. Рассчитывался индекс как отношение числа лиц старше трудоспособного возраста, которых в России относят к категории пожилых, к числу детей в возрасте до 15 лет. В данном анализе классификация полученных значений индекса была приведена в соответствие со стадиями демографического старения по Г. Пеневу [Чистова, 2017]. Так, было выделено 2 класса значений: $0,94-1,25$, соответствующий «глубокой старости», и 1,25-2,4«очень глубокой старости».

Третий этап - построение и анализ интегральной карты потенциала человеческих ресурсов. Цель этапа - получение общей оценки потенциала человеческих ресурсов аграрных территорий по комплексу показателей: численности, плотности и индексу старения. Принцип - чем больше численность и плотность населения и ниже индекс старения сельского поселения, тем благоприятнее потенциал человеческих ресурсов. Тематические карты, полученные на предыдущем этапе, были переведены в растровый формат и переклассифицированы. Далее, с помощью инструмента «Калькулятор растра» было проведено наложение этих карт и выделены сельские поселения с наиболее благоприятным человеческим потенциалом.

\section{Результаты}

В Волгоградской области наиболее распространены сельские поселения с числом жителей от 500 до 2000 чел., в совокупности на них приходится 76,4 \% всех сельских поселений региона (см. табл. 1)

Пространственный анализ сельских поселений по численности жителей, несмотря на неравномерность их размещения (см. рис. 1), не позволяет выделить четких закономерностей. Сельские поселения всех классов чередуются в разных частях муниципальных районов области. Единственное отличие - городской округ Михайловка, возникший при объединении ряда сельских поселений. 
Геоинформационный анализ потенциала человеческих ресурсов аграрных территорий Волгоградской области

\section{Распределение сельских поселений по количеству жителей}

\begin{tabular}{|c|c|c|c|}
\hline № п/п & Классы, чел. & $\begin{array}{c}\text { Количество сельских } \\
\text { поселений }\end{array}$ & $\begin{array}{c}\text { Количество сельских } \\
\text { поселений (\%) }\end{array}$ \\
\hline 1 & $152-500$ & 39 & 9,5 \\
\hline 2 & $501-1000$ & 142 & 34,8 \\
\hline 3 & $1001-2000$ & 170 & 41,6 \\
\hline 4 & $2001-3500$ & 37 & 9,01 \\
\hline 5 & $3501-5500$ & 13 & 3,2 \\
\hline 6 & $5501-7000$ & 5 & 1,2 \\
\hline 7 & $7001-10000$ & 1 & 0,3 \\
\hline 8 & 24393 & 1 & 0,3 \\
\hline
\end{tabular}

Примечание. Составлено авторами по материалам исследования.

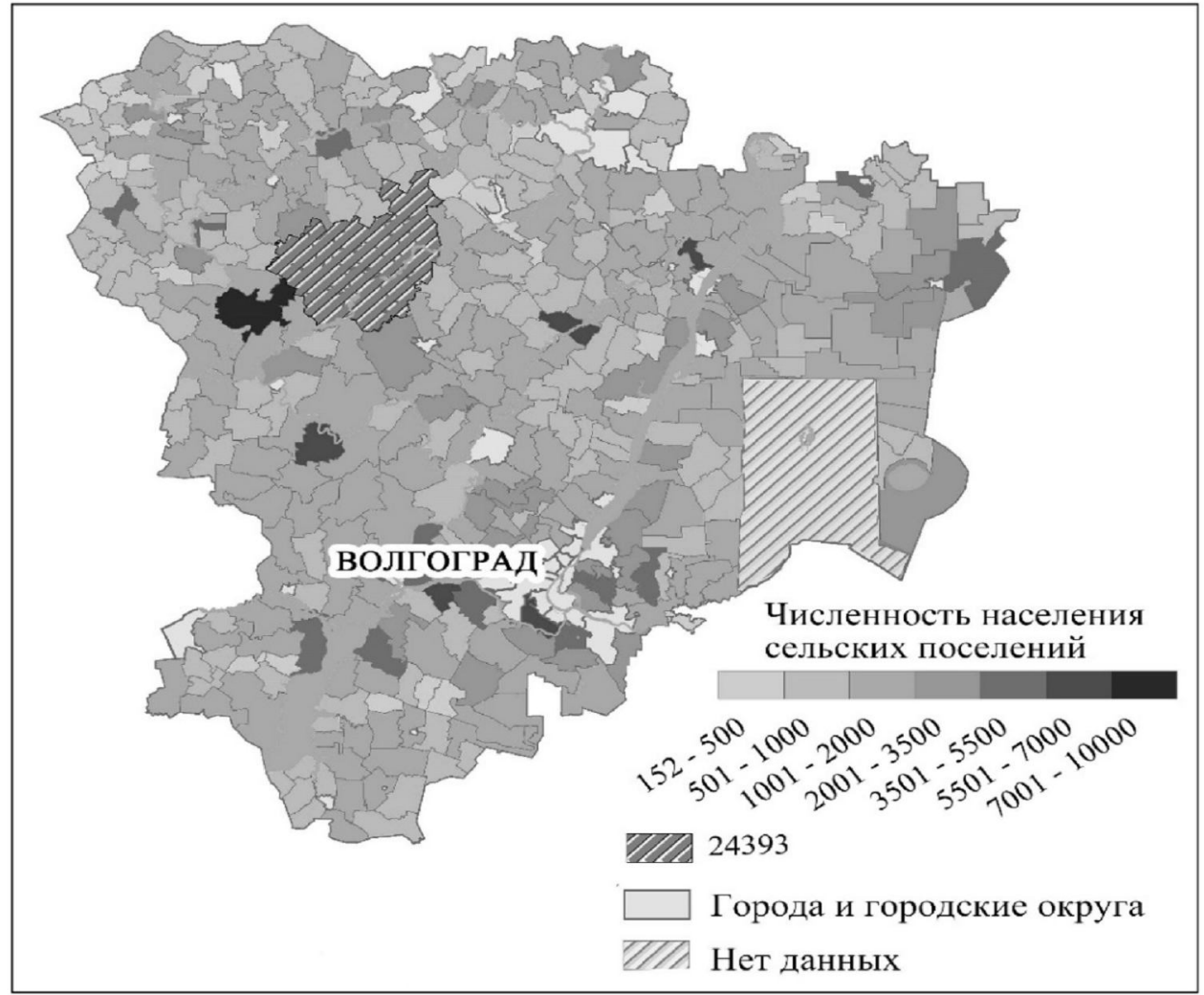

Рис. 1. Численность населения сельских поселений Волгоградской области

Примечание. Составлено авторами.

Средняя плотность сельского населения Волгоградской области составляет 5 чел./км² (2017 г.). Проведенный статистический анализ выявил, что в основной части сельских поселений плотность населения варьируется от 3 до 8 чел./км² (см. табл. 2).

При картографировании плотности населения сельских поселений (см. рис. 2), в отличие от численности, можно выделить чередующиеся зоны повышенной и пониженной плотности сельского населения, в которых этот показатель соответственно выше и ниже среднего значения по Волгоградкой области равного 5 чел./км² (2017 г.). К зонам повышенной плотности сельского населения (> 5 чел./км ${ }^{2}$ ) относится северозападная часть области до р. Медведица, Волго-Иловлинское междуречье и крайний северо-восток области на границе с Саратовской областью и Казахстаном. К зонам пониженной плотности $\left(<5\right.$ чел./км $\left.{ }^{2}\right)$ - территория Медведицко-Иловлинского междуречья, Донское правобережье и центральные области Заволжья. 


\section{Распределение сельских поселений по плотности населения}

\begin{tabular}{|c|c|c|c|}
\hline № п/п & Классы, чел./км ${ }^{2}$ & $\begin{array}{c}\text { Количество сельских } \\
\text { поселений }\end{array}$ & $\begin{array}{c}\text { Количество сельских } \\
\text { поселений (\%) }\end{array}$ \\
\hline 1 & $1-2$ & 64 & 15,7 \\
\hline 2 & $3-4$ & 160 & 39,2 \\
\hline 3 & $5-8$ & 118 & 29 \\
\hline 4 & $9-14$ & 34 & 8,3 \\
\hline 5 & Более 15 & 32 & 7,8 \\
\hline
\end{tabular}

Примечание. Составлено авторами по материалам исследования.

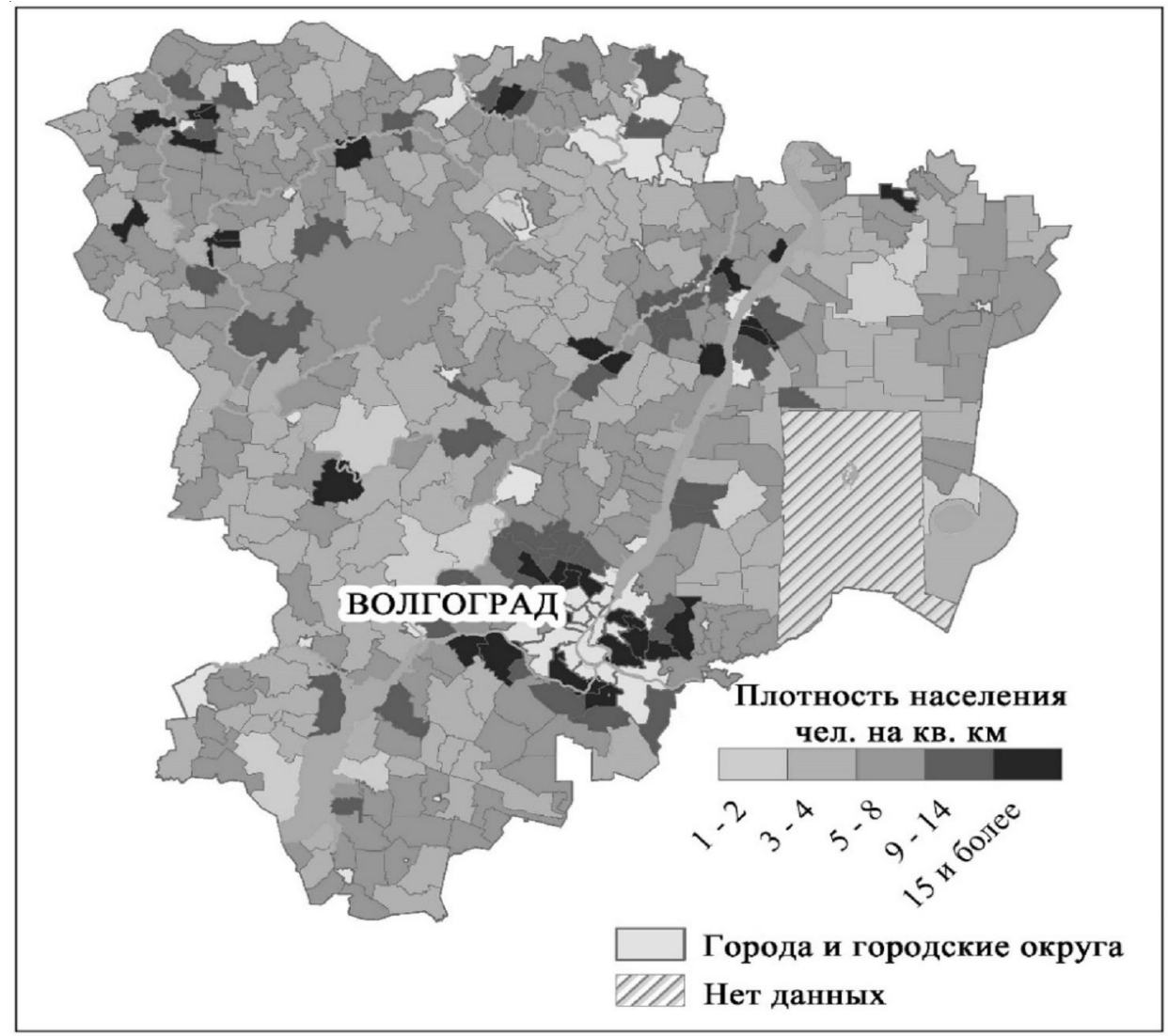

Рис. 2. Плотность населения сельских поселений Волгоградской области

Примечание. Составлено авторами.

Возрастная структура населения региона отражается в неблагоприятных показателях индекса старения (см. рис. 3). Согласно классификации Г. Пенева сельское население Волгоградской области соответствует двум стадиям демографического старения. На стадии очень глубокой старости находится население 28 муниципальных районов, что охватывает основную, центральную часть области. Стадия глубокой старости пока фиксируется в 4 муниципальных районах, расположенных в Заволжье, однако отметим, что два из этих районов - Старополтавский и Быковский - находятся на границе перехода к стадии очень глубокой старости. Самые высокие значения индекса старения (> 2) характерны для районов, расположенных в северной и западной частях области, на границе с Саратовской и Воронежской областью.

Геоинформационный анализ с использованием наложения растровых слоев позволил выделить разные степени благоприятности потенциала человеческих ресурсов сельских территорий (см. рис. 4). 
Геоинформационный анализ потенциала человеческих ресурсов аграрных территорий Волгоградской области

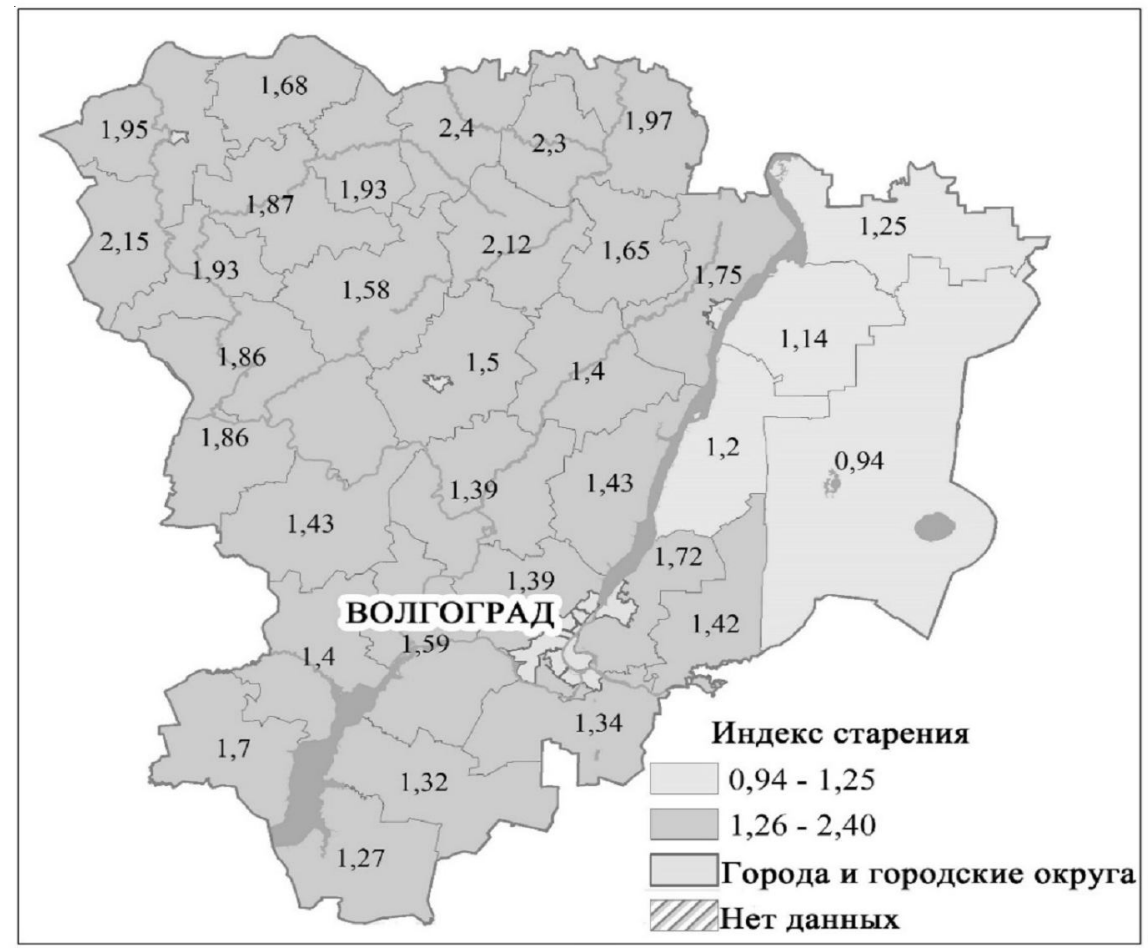

Рис. 3. Индекс старения сельского населения Волгоградской области (интервал значений индекса старения 0,94-1,25 соответствует стадии глубокой старости; 1,26-2,4 - очень глубокой старости)

Примечание. Составлено авторами.

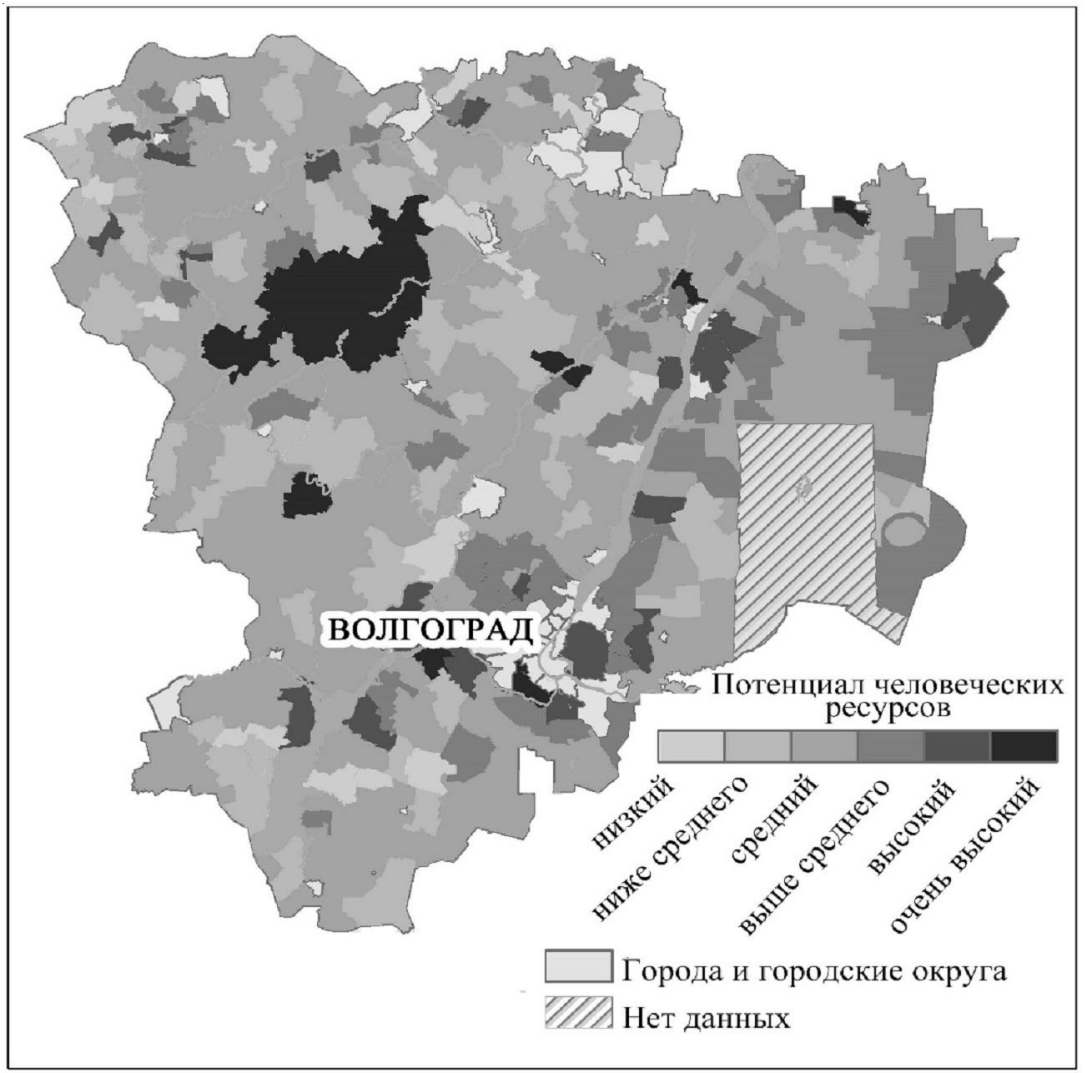

Рис. 4. Степень благоприятности потенциала человеческих ресурсов аграрных территорий Волгоградской области

Примечание. Составлено авторами. 
Классификация проводилась по методу стандартного отклонения. Так, было выделено 6 классов по степени благоприятности: низкая, ниже среднего, средняя, выше среднего, высокая, очень высокая. Проведя территориальный анализ, можно констатировать, что большая часть сельских территорий области находится в условиях среднего значения потенциала человеческих ресурсов. Территории с более высокими значениями тяготеют к городским поселениям, берегам рек, озер и водохранилищ. В целом территориальное распределение потенциала человеческих ресурсов имеет мозаичную структуру.

\section{Заключение}

Большая часть сельского населения Волгоградской области проживает в крупных сельских поселениях, людностью 500-2000 человек. Тем не менее распределено сельское население неравномерно. Анализ плотности сельского населения, которая зависит от численности и площади сельского поселения, привел к выявлению зон повышенной и пониженной плотности по сравнению со среднеобластным значением 5 чел./км². Что касается возрастного состава, то во всех районах региона он соответствует последним стадиям демографического старения. Тем не менее интегральная оценка благоприятности потенциала человеческих ресурсов по комплексу показателей численности, плотности и индексу старения сельского населения, показывает преобладание территорий со средней степенью благоприятности. Территориальная структура потенциала человеческих ресурсов сельских поселений Волгоградской области имеет мозаичную структуру, в которой отсутствуют четко определенные зоны.

Описанная методика геоинформационного анализа человеческих ресурсов аграрных территорий основана на классических подходах экономической картографии и геоинформационного картографирования. Покомпонентный анализ и интегральная оценка картографируемых показателей с использованием ГИС позволяет провести статистический анализ, классификацию, выявить и оценить особенности пространственного распределения.

\section{ПРИМЕЧАНИЕ}

${ }^{1}$ Работа выполнена при финансовой поддержке Администрации Волгоградской области в рамках соглашения о предоставлении из областного бюджета грантов в форме субсидий от 29.11.2019. № 7.

The reported work was carried out with the financial support of the Administration of Volgograd region in the framework of the agreement on the provision of grants from the regional budget in the form of subsidies dated November 29, 2019. No. 7.

\section{СПИСОК ЛИТЕРАТУРЫ}

Аляев, В. А. Сельское расселение как основа устойчивого развития Волгоградской области / В. А. Аляев, М. В. Аляев // Грани познания. 2013. - № 3 (23). - C. 58-69.

Аляев, В. А. Территориальные особенности развития сельского расселения Волгоградской области в конце XX века / В. А. Аляев, Д. А. Семенова // Муниципальные образования современных регионов: проблемы исследования, развития и управления в условиях геоэкономической и экономической нестабильности : материалы Первой Междунар. науч.практ. конф. к 80-летию кафедры социально-экономической географии и регионоведения. Воронеж : Научная книга, 2016. - С. 12-14.

Анализ пастбищных ресурсов Волгоградской области в геоинформационной системе / С. С. Шинкаренко [и др.] // Известия Нижневолжского агроуниверситетского комплекса: Наука и высшее профессиональное образование. 2019. - № 1 (53). - C. 123-130.

Вишняков, Н. В. Социально-экономическая ретроспектива заселения и освоения района малой излучины реки Дон на примере бассейна реки Большая Голубая / Н. В. Вишняков, Д. А. Семенова // Проблемы региональной экологии. 2016. -№ 1. - C. 92-100.

Галин, Р. А. Расселение сельского населения как фактор развития сельского хозяйства / Р. А. Галин // Экономика и управление : науч.-практ. журн. 2015. -№5 (127). - C. 28-30.

Егоров, Д. О. Сельское расселение России: типология территорий по людности сельских населенных пунктов / Д. О. Егоров, В. С. Шурупина // Региональные исследования. - 2018. № 4 (62). - C. 4-16.

Ивлиева, Н. Г. Геоинформационно-картографическое обеспечение исследований пространственно-временных особенностей сельского расселения республики Мордовия / Н. Г. Ив- 
лиева, В. Ф. Манухов // ИнтерКарто. ИнтерГИС. $-2017 .-$ Т. 23, № 2. - С. 64-77.

Муниципальная статистика. - Электрон. текстовые данные. - Режим доступа: https://volgastat. gks.ru/municipal_statistics (дата обращения: 15.02.2020). - Загл. с экрана.

Руднева, О. С. Структурная эволюция сети сельского расселения в регионах степной зоны России / О. С. Руднева, А. А. Соколов // Russian Economic Bulletin, 2019. - T. 2. - C. 280-285.

Тимонин, С. А. Геоинформационные модели расселения населения и их применение / С. А. Тимонин, В. М. Яблоков // ArcReview. - 2011. - № 3.C. 7 .

Тойн, П. Методы географических исследований / П. Тойн, П. Ньюби. - М. : Прогресс, 1977. Вып. 1: Экономическая география. - 271 с.

Чистова, Е. В. Подход к определению стадии демографического старения населения на региональном уровне / Е. В. Чистова // Сборник статей VIII Уральского демографического форума. - Екатеринбург : Институт экономики Уральского отделения РАН, 2017. - С. 489-496.

Alekseev, A. I. Transformation Trends of Russia's Rural Settlement Patterns in the Late Soviet and Post-Soviet Periods (1970-2010) / A. I. Alekseev, S. G. Safronov // Reg. Res. Russ. - 2015. № 2 (5). - P. 193-201.

Freeman, L. C. Centrality in Social Networks Conceptual Clarification / L. C. Freeman // Social Networks, 1978. - № 3 (1). - P. 215-239.

Pitts, F. R. A Graph Theoretic Approach to Historical Geography/ F. R. Pitts // Prof. Geogr. - 1965. № 17 (5). - P. 15-20.

\section{REFERENCES}

Alyaev V.A., Alyaev M.V. Selskoe rasselenie kak osnova ustoychivogo razvitiya Volgogradskoy oblasti [Rural Resettlement as the Basis for Sustainable Development of the Volgograd Region]. Grani poznaniya [Brink of Knowledge], 2013, no. 3 (23), pp. 58-69.

Alyaev V.A., Semenova D.A. Territorialnye osobennosti razvitiya selskogo rasseleniya Volgogradskoy oblasti v kontse XX veka [Territorial Features of the Development of Rural Settlement of Volgograd Region at the End of the $20^{\text {th }}$ Century]. Munitsipalnye obrazovaniya sovremennykh regionov: problemy issledovaniya, razvitiya $i$ upravleniya $v$ usloviyakh geoekonomicheskoy $i$ ekonomicheskoy nestabilnosti: materialy Pervoy Mezhdunar. nauch.-prakt. konf. $k$ 80letiyu kafedry sotsialno-ekonomicheskoy geografii i regionovedeniya [Municipalities of Modern Regions: Problems of Research, Development and Management in the Conditions of Geo-Economic and Economic Instability. Proceedings of the $1^{\text {st }}$ International Scientific and Practical Conference to the $80^{\text {th }}$ Anniversary of the Department of Socio-Economic Geography and Regional Studies]. Voronezh, Nauchnaya kniga Publ., 2016, pp. 12-14.

Shinkarenko S.S., Kosheleva O.Yu., Solodovnikov D.A., Pugacheva A.M. Analiz pastbishchnykh resursov Volgogradskoy oblasti $\mathrm{V}$ geoinformatsionnoy sisteme [Analysis of the Pastural Resources of the Volgograd Region in the Geoinformation Systems]. Izvestiya Nizhnevolzhskogo agrouniversitetskogo kompleksa: Nauka i vysshee professionalnoe obrazovanie [News of the Lower Volga AgroUniversity Complex: Science and Higher Professional Education], 2019, no. 1 (53), pp. 123-130.

Vishnyakov N.V., Semenova D.A. Sotsialnoekonomicheskaya retrospektiva zaseleniya i osvoeniya rayona maloy izluchiny reki Don na primere basseyna reki Bolshaya Golubaya [Socio-Economic Retrospective of the Settlement and Development of the Low Bend of the Don River on the Example of the Great Blue River Basin]. Problemy regionalnoy ekologii [Problems of Regional Ecology], 2016, no. 1, pp. 92-100.

Galin R.A. Rasselenie selskogo naseleniya kak faktor razvitiya selskogo khozyaystva [The Settlement of the Rural Population as a Factor in the Development of Agriculture]. Ekonomika $i$ upravlenie: nauch.-prakt. zhurn. [Economics and Management: Scientific and Practical Journal], 2015, no. 5 (127), pp. 28-30.

Egorov D.O., Shurupina V.S. Selskoe rasselenie Rossii: tipologiya territoriy po lyudnosti selskikh naselennykh punktov [Rural Settlement of Russia: Typology of Territories by Population of Rural Settlements]. Regionalnye issledovaniya [Regional Researches], 2018, no. 4 (62), pp. 4-16.

Ivlieva N.G., Manukhov V.F. Geoinformatsionnokartograficheskoe obespechenie issledovaniy prostranstvenno-vremennykh osobennostey selskogo rasseleniya respubliki Mordoviya [Geoinformation-Cartographic Support for Studies of the Spatio-Temporal Features of Rural Settlement of the Republic of Mordovia]. InterKarto. InterGIS, 2017, vol. 23, no. 2, pp. 64-77.

Munitsipalnaya statistika [Municipal Statistics]. URL: https://volgastat.gks.ru/municipal_statistics (accessed 15 February 2020). 
Rudneva O.S., Sokolov A.A. Strukturnaya evolyutsiya seti selskogo rasseleniya $\mathrm{v}$ regionakh stepnoy zony Rossii [Structural Evolution of the Rural Settlement Network in the Regions of the Steppe Zone of Russia]. Russian Economic Bulletin, 2019, vol. 2, pp. 280-285.

Timonin S.A. Geoinformatsionnye modeli rasseleniya naseleniya i ikh primenenie [Geoinformation Models of Population Distribution and Their Application]. ArcReview, 2011, no. 3, p. 7.

Metody geograficheskikh issledovaniy. Vyp. 1: Ekonomicheskaya geografiya [Geographic Research Methods. Vol. 1: Economic Geography]. Moscow, Progress Publ., 1977. 271 p.

Chistova E.V. Podkhod k opredeleniyu stadii demograficheskogo stareniya naseleniya na regionalnom urovne [Approach to Determining the Stage of Demographic Aging of the Population at the Regional Level]. Sbornik statey VIII Uralskogo demograficheskogo foruma [Collection of Articles of the $8^{\text {th }}$ Ural Demographic Forum]. Yekaterinburg, Institut ekonomiki Uralskogo otdeleniya RAN, 2017, pp. 489-496.

Alekseev A.I., Safronov S.G. Transformation Trends of Russias Rural Settlement Patterns in the Late Soviet and Post-Soviet Periods (1970-2010). Reg. Res. Russ, 2015, no. 2 (5), pp. 193-201.

Freeman L.C. Centrality in Social Networks Conceptual Clarification. Social Networks, 1978, no. 3 (1), pp. 215-239.

Pitts F.R. A Graph Theoretic Approach to Historical Geography. Prof. Geogr., 1965, no. 17 (5), pp. 15-20.

\section{Information About the Authors}

Natalya M. Khavanskaya, Candidate of Sciences (Geography), Associate Professor, Department of Geography and Cartography, Volgograd State University, Prosp. Universitetsky, 100, 400062 Volgograd, Russian Federation, khavanskaya@volsu.ru, https://orcid.org/0000-0001-9217-6529

Vladimir A. Alyaev, Candidate of Sciences (Geography), Associate Professor, Department of Geography and Cartography, Volgograd State University, Prosp. Universitetsky, 100, 400062 Volgograd, Russian Federation, alyaev@volsu.ru,https://orcid.org/0000-0003-3742-9444

Diana A. Semenova, Senior Lecturer, Department of Geography and Cartography, Volgograd State University, Prosp. Universitetsky, 100, 400062 Volgograd, Russian Federation, semenova@volsu.ru, https://orcid.org/0000-0003-3247-7543

\section{Информация об авторах}

Наталья Михайловна Хаванская, кандидат географических наук, доцент кафедры географии и картографии, Волгоградский государственный университет, просп. Университетский, 100, 400062 г. Волгоград, Российская Федерация, khavanskaya@volsu.ru, https://orcid.org/0000-0001-9217-6529

Владимир Алексеевич Аляев, кандидат географических наук, доцент кафедры географии и картографии, Волгоградский государственный университет, просп. Университетский, 100, 400062 г. Волгоград, Российская Федерация, alyaev@volsu.ru, https://orcid.org/0000-0003-3742-9444

Диана Александровна Семенова, старший преподаватель кафедры географии и картографии, Волгоградский государственный университет, просп. Университетский, 100, 400062 г. Волгоград, Российская Федерация, semenova@volsu.ru, https://orcid.org/0000-0003-3247-7543 